\title{
Chris Jones, Eclipse of Empire? Perceptions of the Western Empire and its Rulers in Late-Medieval France
}

\section{G. Matteo Roccati}

\section{Q OpenEdition}

1 Journals

\section{Édition électronique}

URL : http://journals.openedition.org/studifrancesi/5864

DOI : $10.4000 /$ studifrancesi.5864

ISSN : 2427-5856

\section{Éditeur}

Rosenberg \& Sellier

\section{Édition imprimée}

Date de publication : 1 mai 2011

Pagination : 147

ISSN : 0039-2944

\section{Référence électronique}

G. Matteo Roccati, «Chris Jones, Eclipse of Empire? Perceptions of the Western Empire and its Rulers in Late-Medieval France », Studi Francesi [En ligne], 163 (LV | I) | 2011, mis en ligne le 30 novembre 2015, consulté le 08 janvier 2021. URL : http://journals.openedition.org/studifrancesi/5864 ; DOI : https:// doi.org/ERREUR PDO dans /localdata/www-bin/Core/Core/Db/Db.class.php L.34 : SQLSTATE[HY000] [2006] MySQL server has gone away

Ce document a été généré automatiquement le 8 janvier 2021.

\section{(c) (i) $\odot$}

Studi Francesi è distribuita con Licenza Creative Commons Attribuzione - Non commerciale - Non opere derivate 4.0 Internazionale. 


\title{
Chris Jones, Eclipse of Empire? Perceptions of the Western Empire and its Rulers in Late-Medieval France
}

\author{
G. Matteo Roccati
}

\section{RÉFÉRENCE}

CHRIS JONES, Eclipse of Empire? Perceptions of the Western Empire and its Rulers in Late-

Medieval France, Turnhout, Brepols, 2007 («Cursor mundi», 1), pp. XXIV-416.

1 A partir des sources historiographiques (au sens le plus large possible: chroniques, traités, pamphlets, etc.) et en se référant constamment au contexte d'écriture et de diffusion, l'ouvrage explore la manière dont ont été perçus en France du nord l'Empire et ses gouvernants entre 1240 et 1340 environ, période qui voit l'Empire s'effondrer et la puissance du roi de France s'affirmer. Les premiers chapitres (I-III) sont consacrés aux figures de Frédéric II (et de ses successeurs) et de saint Louis, suivis d'un chapitre (IV) traitant de l'image de Charlemagne. L'A. étudie ensuite l'influence des préoccupations liées à la légitimité dynastique sur la conception de l'élection impériale (V), le refus de la primauté revendiquée par l'Empire (VI) et les limites de la juridiction de ce dernier (VII). En conclusion, un dernier chapitre (VIII) montre la permanence d'un idéal d'autorité supra-national au-delà d'une conception de l'Empire comme entité territoriale limitée. Cette autorité, que les rois de France ambitionnent d'acquérir ou d'incarner, est marquée par le lien avec la papauté et se réalise surtout dans la conduite de la croisade. Tableaux généalogiques, bibliographie (pp. 367-405) et index complètent le volume. 